\title{
Challenge and Opportunity of Small Scale Irrigation in Assosa District, Benishangul Gumuz Region, Ethiopia
}

\author{
Sisay Mekonnen Zewuditu Yirige Ashenafi Girma \\ Department of Soil and Water Resource Management, Assosa University, College of Agriculture and Natural \\ Resource, PO box 18, Assosa, Ethiopia
}

\begin{abstract}
This study was conducted to assess the challenge and opportunity of small scale irrigation in Amba four kebele, Assosa District, Benishangul Gumuz Region, western Ethiopia in the year 2019. In the kebele farmer's grow different cereals, vegetable and fruit and soil types was mostly dominated by clay red which have medium soil fertility. To undertake this research data was collected by questionnaires and interviews from 61 sample respondents and kebele agriculture experts. The data was analyzed by Statistical Package for Social Science and presented by like table, percentage and graph. There are so many challenges faced in the kebele based on the questionnaires survey $50 \%$ of the respondent are exposed to those serious factors i.e. lack of irrigation awareness, lack of water saving technologies, lack adequate base line about irrigation, lack of experience in design and supervision about irrigation project and poor economic back ground. Finally the research finding was concluded that there were different output/results based on the research objectives according to the challenges of small-scale irrigation $11.5 \%$ of the respondent were exposed to different conflict/disagreement due to shortage of sufficient irrigation system and low capacity of water on the area and on the contrary we have generalized that there have been good opportunities according to our finding $98.4 \%$ of the respondent are agree as result of irrigation they have an opportunity to produce crops and vegetables by gaining water from their irrigation system. As a result this irrigation technology used as source of income, maximizing of food production, reduction of poverty. The efficient and effective use of the water resource in irrigation region is central to the long term sustainability of irrigated region in the area. Finally we have been suggest different point of view based our finding we recommended to the concerned bodies such as Assosa District agriculture office, Amba four kebele agriculture office and farmers to work hormonally to each other sought solution for small-scale irrigation challenges and the government should give attention on those critical issues.
\end{abstract}

Keywords: small scale Irrigation, Challenge, Opportunities, Farmers, Respondents

DOI: $10.7176 / \mathrm{JRDM} / 81-01$

Publication date: December $31^{\text {st }} 2021$

\section{Background and Problem Justification}

Agriculture is the backbone of the Ethiopian economy which contributed $41.6 \%$ to (GTP, 2010). It also provides raw material to industrial sector, export items and is major source of employment for $84 \%$ Ethiopia population. Cognizant to this fact, the country focused its development policy, that is, Agricultural Development Led Industrialization (ADLI) on agriculture to transform the economy .ADLI aims for boosting agricultural productivity and improving the rural standard of living, which in turn increase the demand for goods and services and further lead to industrial development. One of the impetuses to achieve the agricultural policy objective is the promotion of irrigation agriculture and integrates water resource management (ADLI, 1994).

In Ethiopia; traditional irrigation had been practice since the ancient times. However, modern irrigation development is start during imperial regime in 1950s with large scale irrigation and hydroelectric power projects (Berhanu and Peden, 2002).So Irrigation is seen as the means of ensuring food security in Ethiopia. Thus the use of modern, advanced and resource efficient irrigation technologies is vital to increase farm output and take people out of poverty.The then large scale irrigation projects are intended to produce crops used for inputs of agroindustries. The Derge regime gave emphasis in development of large, small and mediumirrigation schemes to mitigate drought and famine (ibid.).The Ethiopian People Democratic Front (EPRDF), the current regime, like its predecessors enthusiastic in developing irrigated agriculture. Thus, it has developed an irrigation policy that aims developing the huge irrigated agriculture potential for the production of food crops and raw materials needed for agro industries, in an efficient and sustainable basis and without degrading the fertility of the productionfields and water resources base (MoWR, 2001).Though such attempts have been done for the last 45 years, the country still used 5 to $10 \%$ of 3.7 million hectares of irrigated potential area.

Irrigation agriculture produces less than $3 \%$ of the total food production of the Country. Hence, though successive regimes of Ethiopia have attempted to boost irrigated agricultural production through irrigation development, the country still could not exploit its irrigation potential efficiently and effectively. Instead, the country is highly dependent on rain fed agricultural production system. Small irrigation is the application of artificial water with small area of land up to less than 200ha which diversion weir made up of local material small irrigation the system of using the collect water from by different water collecting techniques such as roof water 
harvesting, micro catchment, macro catchment and flood water harvesting to store water and used it for growing different agricultural output such as creel crop, fruit, vegetable and other agricultural output (Bekele et al., 2012). The beginning of irrigation in Ethiopia strongly associated with the ancient civilization of Axum north of parts of Ethiopia. In the highland of Ethiopia irrigation practices have been such longer ages since past period for production of subsistence food crop (Awulachew et al., 2007).

The supplementary irrigation has been practiced by small holder farmers of Ethiopia for many centuries to solve their livelihood challenge (Hagos et al., 2009). Modern irrigation is started in the early 1950s by bilateral agreement between the governments of Ethiopia during degree regime with Dutch jointly for sugar production. Challenges regarding to development of small irrigation system are include pre-dominantly nature of production system, shortage of enough agriculture in put such as fertilizer, modern, labor and enough capital, limited technologies, inadequate extension service due to above condition irrigations system contributes about $2.5 \%$ of overall GDP (MoA, 2011b).

These challenges can be explained as technical constraints and knowledge gaps as (1) inadequate awareness of irrigation water management as in irrigation scheduling techniques, water saving irrigation technologies, water measurement techniques, operation and maintenance of irrigation facilities, (2) inadequate knowledge on improved and diversified irrigation agronomic practices, (3) shortage of basic technical knowledge on irrigation pumps, drip irrigation system, sprinkler irrigations, surface and spate irrigation methods (4) scheme based approach rather than area/catchments based approach for the development of SSI Schemes, (5) inadequate baseline data and information on the development of water resources, (6) lack of experience in design, construction and supervision of quality irrigation projects, (7) low productivity of existing irrigation schemes, (8) inadequate community involvement and consultation in scheme planning, construction and implementation of irrigation development, (9) poor economic background of users for irrigation infrastructure development, to access irrigation technologies and agriculturalinputs, where the price increment is not affordable to farmers (FAO, 2012). There is a lot of opportunities to practice that enhance irrigation practice due to plenty resource of water and geographical location of the country (MoA, 2011a).Irrigation can included increase food production in rainfall lack area such as arid and Sami- arid area, enhance food production, promote economic growth, sustainable development, create employment, improving living condition of small-farmers and contribute to the poverty reduction (Abraham et al., 2011).

Ethiopia faces so many challenges to generate well promising benefit from irrigation. All most in all Ethiopians farmers are practiced very primitive way of irrigation system. The outcomes of the irrigation productivity are affected due to natural human and past and current condition of irrigation practice. Backward practice and lack of skilled man power and the technology are the main problem or our challenges that facing Ethiopia to generate well defines output from irrigation. Similarly, small scale irrigation practice in our study area is not that much suitable. That means farmers are not well intensively engaged to the activity. This shows that even if it is not well identified and documented they do have a sort of constraint's that limit their practices. Accordingly, this study was motivated to identify and document the challenges and opportunities of small scale irrigation practices in Assosa District, Benishangul Gumuz Region, Ethiopia.

\section{Materials and Methods}

\subsection{Description of the study Area}

This study was conducted in Assosa District, Benishangul Gumuz Region, Western Ethiopia. Assosa District is bordered in the North West direction by Kurmuk and Homosha District of Benishangul Gumuz Region; it is bordered in the Southern Direction by Mao Komo Special District of Benishangul Gumuz Region. The District is bordered in the West direction by Sudan and in the Eastern direction bordered by Bambasi District of Benishangul Gumuz Region. It is located at an altitudinal range of $1570 \mathrm{~m}$ above sea level and the geographic location of the study area is range between $09.17^{0} \_12.06^{\circ} \mathrm{N}$ latitudes and $34.10^{0} \_37.04^{\circ} \mathrm{E}$ longitudes. (Assosa District BoARD, 2018). 


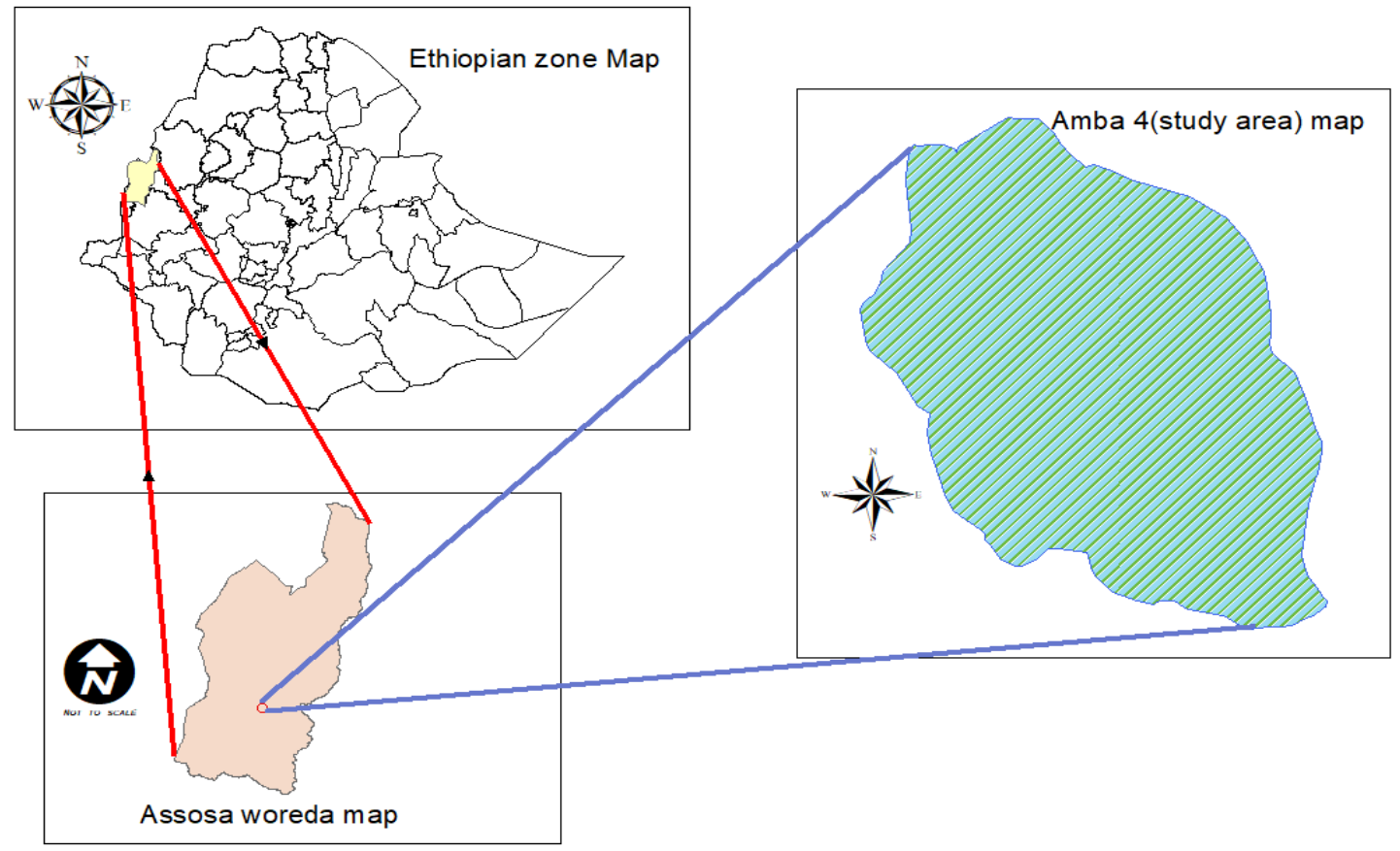

Figure 1: Map of the Study Area

The agro ecological zone of Assosa district is fully Kola. The average temperature of the district is $27{ }^{0} \mathrm{C}$. The rainfall pattern of the district is monomodal rainfall distribution. The rainy season starts in May and extends to October and the dry season starts in November and extends up to end of April. The dry season have a wider temperature differences mainly on the onset it is too cold in the morning and at the night and too hot in the midday. The dry season in the district has also a windy and cloudy nature. The annual rainfall of district ranges between $900 \mathrm{~mm}$ to $1400 \mathrm{~mm}$ by using the moisture available from rain water most of the crops are cultivated in the district( Assosa Agricultural Development Office,2014). Assosa District depends on agricultural products. The commonly produced field crops are Maize, Sorghum, soybean, finger millet, sesame etc. The commonly cultivated vegetable crops are Tomatoes, Onion and Pepper. Assosa District has high domestic animal resources the commonly raised ones are Cattle, Goat, Donkey, Mule and Poultry. The human population in Assosa District is totally 87,366. Out of these 44,176 are males and 43,190 are females. The total rural households in the District are 18,125 out of these 14,678 are male headed household and 3,447 are female headed household. The average family size of per household in the district is 5 (Assosa District Agricultural Development Office, 2014).

\subsection{Data Collection Method}

The primary data were collected directly from kebele households by face to face interview, and physical observation. These data were collected from different published and unpublished documents, project reports and government officials.

\subsection{Sampling technique and Sample size}

For this study Amba four kebele is preferably selected considering the potential of irrigation and its accessibility for the study The sample size of this study were determined by using Out of 160 household heads of the kebele, 61 house hold heads there is used as a sample respondent for this study as it is given below

Where, $n=$ Sample size

$$
\mathrm{n}=\frac{N}{1+N(e) 2}
$$

$N=$ Number of household

$e=$ significance level $=0.05$

$$
\mathrm{n}=\frac{160}{1+160(0.1)^{2}}=61
$$




\subsection{Methods of data collection}

To obtain all required data effectively and efficiently both qualitative and quantitative data were used. Data collected from primary source like respondents. The secondary sources there collected from review the relevant material such as research documents, books reports and documentary source located in the study area and internet service. Interview are organized in a way that respondents were provide valuable information on the topic of the research and solution there provided on how to utilize the opportunities created much further. Semi -structured questionnaire are used for interviewing the respondents. Personal observation there used in order to have a chance to practically observe the challenges and opportunities of farmers in small-scale irrigation practice in our case study area.

\subsection{Data Analysis and Presentation}

Descriptive analysis is used to summarize the information or data collected from the sample respondents. Data processing is the transformation of raw data in to some processed data to facilitate the study. It includes, editing, coding and classification. The quantitative data collected by interview (semi-structured questionnaire) analyzed, organized and presented by using descriptive statistics such as percentage, frequency, table, charts and graph using Statistical Package for Social Science (SPSS) version 20 and the qualitative data are analyzed by conceptual, general, narration and interpreting for different qualitative questions.

\section{Result And Discussions}

3.1. Respondents' characteristics

Table 1: Age and Sex of respondents

\begin{tabular}{llll}
\hline Respondents characteristics & Category & Frequency & Percent \\
\hline Age & $20-30$ & 14 & 23 \\
& $30-40$ & 12 & 19.75 \\
$40-50$ & 10 & 16.4 \\
& $50-60$ & 17 & 27.9 \\
& $>60$ & 8 & 13.1 \\
Sex & Total & 61 & 100 \\
& Male & 47 & 77 \\
& Female & 14 & 23 \\
& Total & $\mathbf{6 1}$ & $\mathbf{1 0 0}$
\end{tabular}

Based on table 1 above, the age of respondents in the studies area were $23 \%$ between $20-30,19.7 \% \mathrm{~b} / \mathrm{n} 30-40$, $16.4 \%$ 40-50, 27.9\%50-60 and 13.1\%is above 60 years old. In general most of the respondents in the study area were the age $\mathrm{b} / \mathrm{n} 50-60$. Again Table1 above shows that males take high proportion accounting $77 \%$ of the total respondents and $23 \%$ are female. Thus the participation of females is relatively low. This is because they were not voluntary to respond the questionnaire, not only this but also cultural influence and they were probably invited the questionnaire to their participation nearby friends and to their husband. Therefore, their participation should be increased through avoiding the above stated problem and by creating awareness of them.

\subsection{Crop production Pattern}

Table 2: Crop production pattern of the study area

\begin{tabular}{|c|c|c|c|}
\hline Variable & Category & Frequency & Percent \\
\hline How many & Once & 11 & $18 \%$ \\
\hline times you can & Twice & 7 & $11.5 \%$ \\
\hline Produce crop, & Three & 43 & $70.5 \%$ \\
\hline vegetable and & Total & 61 & $100 \%$ \\
\hline
\end{tabular}

fruit pre year?

Table 2 , shows that $11.5 \%$ of respondents reported that they produce twice per year and $70.5 \%$ of respondents reported that they able to produce three times per year. This shows that majority of farmer's produce three times per year. From the rain fed users all respondents reported that they able to produce only ones per years.

\subsection{Access for Extension service}

Table 3: Access to extension service

\begin{tabular}{lccl}
\hline Variable & Category & Frequency & Percent \\
\hline Where do you & Office & 30 & $40.2 \%$ \\
get Extension & & 31 & $50.8 \%$ \\
service? & Farm & $\mathbf{6 1}$ & $\mathbf{1 0 0 \%}$ \\
\hline
\end{tabular}


Table 3, shows that 50.8 percent of respondents from irrigation users who were access to extension services reported that they obtain extension services at their farm and 40.2 percent of respondents reported that they obtain extension services at the office. The survey result show thatmajority of respondents (household) who were access to extension service obtain from their farm.

\subsection{Access for irrigation technology}

Table4: Accessibility of Irrigation technologies

\begin{tabular}{lccl}
\hline Variable & Category & Frequency & Percent \\
\hline Do you have & Yes & 35 & $57.4 \%$ \\
any Irrigation & & & $42.6 \%$ \\
technology? & No & 26 & $\mathbf{1 0 0 \%}$ \\
\hline
\end{tabular}

From table 4 above, the accessibility of irrigation technologies were $57.4 \%$ and the remaining $42.6 \%$ shows that the limitation in irrigation technologies accessibility. It indicate that lack of capital, lack of knowledge ,lack of experience the major problem of irrigation user as the respondents has narrated via our open ended questions.

\subsection{Opportunity of small scale irrigation in the study area}

The basic opportunities of small- scale irrigation increased agricultural production to meet the growing food demands of rapid population growth, food security, promotes economic growth and sustainable development, create employment opportunities, and improve living conditions of small-scale farmer. As a result, irrigation contributes to poverty reduction and protects the environment from degradation and pollution. Furthermore, it increases subsurface water levels and recharges groundwater.

Table 5: Opportunities of small scale irrigation

\begin{tabular}{lccc}
\hline Variable & \multicolumn{3}{c}{ Percent } \\
\hline Can you believe that small scale irrigation have created an & Yes & 60 & $98.4 \%$ \\
Opportunists for food security to your? & No & 1 & $1.6 \%$ \\
& Total & $\mathbf{6 1}$ & $\mathbf{1 0 0 \%}$ \\
\hline
\end{tabular}

Table 5 above, shows that $98.4 \%$ agree as result of irrigation they have an opportunity to produce crops and vegetables by gaining water from their irrigation system. As a result this irrigation technology used as source of income, maximizing of food production, reduction of poverty and also have a great opportunity in extension service, the efficient and effective use of the water resource in irrigation region is central to the long term sustainability of irrigated region in the area.

\subsection{Market accessibility}

Table 6: Market accessibility in the study area

\begin{tabular}{|c|c|c|c|}
\hline Variable & Category & Frequency & Percent \\
\hline Do you gain & Yes & 55 & $90.1 \%$ \\
\hline Market & No & 6 & $9.8 \%$ \\
\hline access? & Total & 61 & $100 \%$ \\
\hline
\end{tabular}

From the above table $6,90.1 \%$ of the respondent said that there were good market accessibilty on the area. That means there were different suitable condition the area such as the market is near to the product, the cost of crops and vegetables were balanced and have low transportation cost.on the contrary $9.8 \%$ of the respondent were the reverse of the above.

\subsection{Types of small-scale Irrigation}

Table 7: Types of small-scale Irrigation on the study area

\begin{tabular}{llll}
\hline Variable & Category & Frequency & Percent \\
\hline Which small scale Irrigation type do you use? & Modern micro dam & 3 & $4.9 \%$ \\
& Traditional river diversion & 58 & $95.1 \%$ \\
& Total & 61 & $100 \%$ \\
\hline
\end{tabular}

From the above table 7: the respondent of modern micro dam $4.9 \%$ the percentage of Modern micro dam was very low it indicated that there were no capital or resources to construct such kinds of small-scale irrigation and 95.1\% traditional river diversion these indicted that it was easy to use traditional river diversion rather than modern micro dam. 


\subsection{Availability of water for Irrigation}

Table 8: The amount of water to irrigate on the area

\begin{tabular}{llll}
\hline variable & Category & Frequency & Percent \\
\hline Is the Amount of water enough to irrigate your land? & Yes & 41 & $67.2 \%$ \\
& No & 20 & $32.8 \%$ \\
& Total & 61 & $100 \%$ \\
\hline
\end{tabular}

Table 8: indicates that $67.2 \%$ of the respondents have got enough water for their irrigation purpose and $32.8 \%$ have not got enough water access for irrigation due to lack of rain fall, soil type and topography.

\subsection{Water Application methods}

Table 9: Application methods of water on the study area

\begin{tabular}{llll}
\hline Variable & Category & Frequency & Percent \\
\hline What type of water Application method you use? & Flooding & 2 & $3.3 \%$ \\
& Furrow irrigation & 26 & $42.6 \%$ \\
& Sprinkle irrigation & 1 & $1.6 \%$ \\
& Surface irrigation & 32 & $52.5 \%$ \\
& Total & 61 & $100 \%$ \\
\hline
\end{tabular}

From the above table 9: the respondents' use of irrigation method show flooding 3.3\%, furrow irrigation $42.6 \%$, sprinkler irrigation $1.6 \%$ and surface irrigation $52.5 \%$.this indicates that most farmers use surface irrigation, to producing different types of farm products like fruit, vegetation, and sugar cane.

\subsection{Challenges of small-scale irrigation}

With regard to the prospects of effective Utilization of Irrigation Technologies, the result of the study has shown that availability of labor, agro-ecology, access to money, access to markets and support of government and NGOs were identified as major challenges or factors which can be prospect for utilization of irrigation technologies. The difficulty in maintaining new irrigation technologies, lack of access to spare parts and shortage of water, lack of training, uncertainty about new irrigation inputs and lack of know-how, were the most serious challenges hindering irrigation development. In addition to that, the income possible from non-crop producing activities is found to be a major inhibitor in the development and utilization of small-scale irrigation technologies. Weakness of Local facilities, Weakness of extension personnel in supporting farmers were also identified as a main hampering pointes of extension service.

Table 10: Challenges of small-scale irrigation on the study area

\begin{tabular}{llll}
\hline Variable & Category & Frequency & Percent \\
\hline Challenges of small-scale irrigation & Yes & 46 & $75.4 \%$ \\
& No & 15 & $24.5 \%$ \\
& Total & $\mathbf{6 1}$ & $\mathbf{1 0 0 \%}$
\end{tabular}

Do you feel you are Sharing equal water with every user in the scheme?

Yes $\quad 61 \quad 100 \%$

Table10 above shows that there were conflicts in the irrigation schemes with the use of their small scale irrigation systems $75.4 \%$ of respondents said that there was conflict during the use of irrigation water while $24.5 \%$ them says there is no conflict among the neighboring community in irrigation water use. The Challenges seem more severe in Amba 4 kebele as per the narration that most respondents give for our open ended questions. Most of the challenges are associated with poor scheme coordination, water theft, water shortages, Lack of transportation, theft of products like fruit, sugar cane, vegetables and threats such as insects. Again table10 above, show that all farmers gain equal access of water distribution, since they irrigate on the same piece of land, divert water in water way, collect water during night.

\subsection{Source of water for small scale irrigation}

The survey result shows that the source of irrigations are river, spring, Well, Pond. The efficient and effective use of the water resource in irrigation region is central to the long term sustainability of irrigated region in the area. The river offers the potential to increase water availability by coupling proper water allocation with efficient use. Means $70 \%$ of the respondents are collected from the river.From figure 2: the result shows that the major source of Small Scale Irrigation got from The River. 


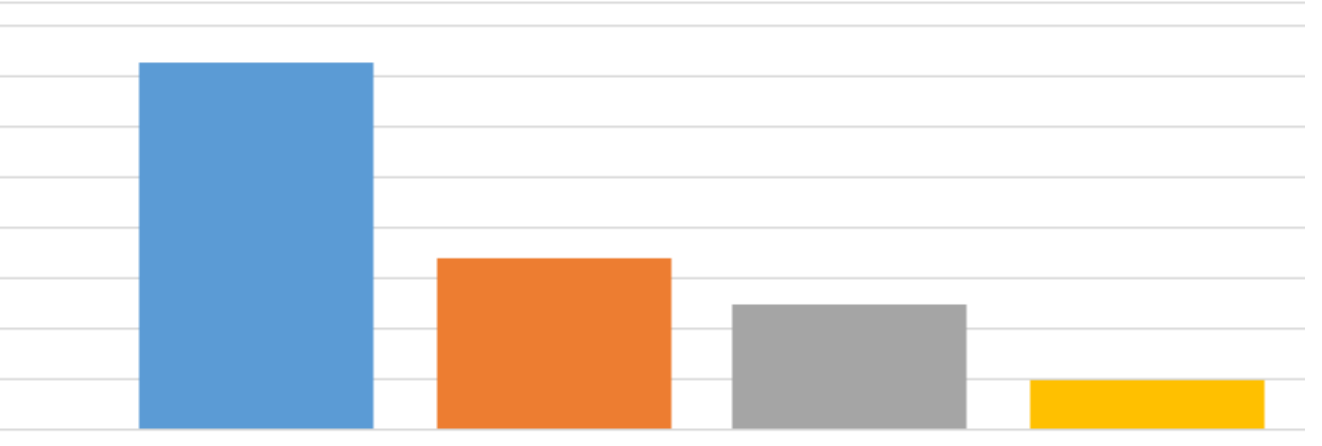

Source of irrigation

- River Well Spring Pond

Figure 2: Source of water for small scale irrigation

\section{Conclusion and Recommendtiion}

After making a detail investigation we have got a lot of challenge's which were identified in the Amba4kebele those serious challenges are shortage of enough water input for irrigation, lack of enough land size to practice of small scale irrigation, lack of labor, lack of enough capital to practice irrigation, inadequate extension service, lack of awarenessabout small-scale irrigation, lack of water savingirrigation technologies. Allof the above challenges have been identified in the kebele. The practice of irrigation have a lot of opportunities to Amba4 kebele those opportunities of small-scale irrigation are increased agricultural production to meet the growing food demands of rapid population growth, to enhance food security, promotes economic growth and sustainable development, create employment opportunities and improve living conditions of small-scale farmer users. As a result, irrigation contributes to poverty reduction and protects the environment from degradation and pollution. Furthermore, it increases subsurface water levels and recharges groundwater. So according to this finding $98.4 \%$ of the respondent have agreed small-scale irrigation system is a best way to fulfill the above opportunities on their kebele. Smallscale irrigation leads to sustainable development creates job opportunity, improving living condition of small scale farmers and contributes to the poverty reduction. Generally we concluded that beside those challenge which existed in the kebele, but small scale irrigation user increasing from year to year which is against challenge which will solved in the future. We have recommended the following issues based on the main finding and which will indicates what to do in the future in order to solve those problems.

$\checkmark$ Irrigation farming to be sustainable, there is need for intervention by interested stakeholders such as community based organizations and co- operatives.

$\checkmark$ Responsible body should ensure that there are good roads and cheap transport which ferry the crops to different places for sustainable small-scale irrigation.

$\checkmark$ The farmer to be co-operated in irrigation to minimize the challenges of small-scale irrigation practice.

$\checkmark$ Farmers should have high interaction with development agent (DAs) at the farm place.

$\checkmark$ Lastly, we recommend it is important to encourage farmers to apply new technology to be successful in small- scale irrigation practice in the study area.

\section{References}

Abraham BG, Nata T, Bheemalingeswara K, Mokennen H (2011). Suitability of Groundwater Quality for Irrigation: A Case Study on Hand Dug Wells in Hantebet Catchment, Tigray, and Northern Ethiopia. J. Am. Sci. 7(8): 191-199.

ADLI (1994). Agricultural Development Led Industrialization. Economic Development policy of Ethiopia Addis Ababa

Awulachew SB, Yilma A, Loulseged D, Loiskandl W, Ayana M, Alamirew T, (2007). Water Resources and Irrigation Development in Ethiopia Colombo, Sri Lanka: International Water Management Institute.

Bekele Y, Nata T, Bheemalingswara K (2012). Preliminary Study on the Impact of Water Quality and Irrigation Practices on Soil Salinity and Crop Production, Gergera Watershed, Atsbi-Wonberta, Tigray,Northern Ethiopia, MEJS. 4(1):29-46.

Berhanu G, Peden D (2002). Policies and Institutions to enhance the Impact of Irrigation Development in Mixed Crop-Livestock Systems: In Integrated water and land management research and capacity building priorities for Ethiopia. Proceedings of Mo WR/EARO/IMWI/ILRI international workshop held at ILRI, Addis Ababa, Ethiopia. December pp. 2-4

FAO (2001a).The economics of conservation agriculture Land and Water Development

Federal Democratic Republic Of Ethiopia Growth and Transformation Plan 20 10/11-2014 / 15 Ministry of 
Finance and Economic Development November 2010 Addis Ababa.

Hagos F, Makombe G, Namara RE, Awulachew SB (2009). Importance of irrigated agriculture to the Ethiopian economy: Capturing the direct net benefits of irrigation. Colombo, Sri Lanka: International Water Management Institute. 37p. (IWMI Research Report128)

Ministry of Water Resources (2001). Data collected from different river basin development master plan studies. Planning and Projects Department, Ministry of Water Resources Addis Ababa Ethiopia

MoA (2011a). Natural Resources Management Directorates Small-Scale Irrigation Situation Analysis and Capacity Needs Assessment, Addis Ababa, Ethiopia

MoA (2011b). Natural Resources Sector, Small-Scale Irrigation Capacity Building Strategy for Ethiopia, Addis Ababa, Ethiopia. 